DOI: https://doi.org/10.24127/ajpm.v10i3.3832

\title{
THE EFFECTIVENESS OF LINEAR SYSTEM MEDIA ON THE THREE VARIABLE LINEAR EQUATION LEARNING SYSTEM
}

\author{
Ari Wahyu Silvana ${ }^{1}$, Dwi Priyo Utomo ${ }^{2}$, Siti Khoiruli Ummah ${ }^{3 *}$ \\ 1,2,3* Universitas Muhammadiyah Malang, Malang, Indonesia \\ *Corresponding author. \\ E-mail: $\frac{\text { ariwahyusilvana@gmail.com }}{{ }^{1)}}$
}

Received 21 June 2021; Received in revised form 12 September 2021; Accepted 27 September 2021

\begin{abstract}
The aim of this study described the effectiveness of instructional media that produces valid, effective, and practical media. The development of communication and technology requires teachers to be more active and creative in carrying out classroom learning. Teachers can develop learning media that can improve student learning outcomes. The sample of this research trial was the students of class X at MAN 1 Mojokerto. This study uses a 4-D research method which is shortened to 3-D. Data collection techniques used include interviews with mathematics teachers, pretest and posttest questions. The instruments used in this study include guidelines for using media, teaching materials, validation sheets, student response questionnaires and tests. The results of this study indicate that the average validation guide for the use of media, and teaching materials is $95.15 \%$, besides that the validator also provides an assessment on the response questionnaire sheet of $97.5 \%$. This indicates that the media guidelines, teaching materials, and response questionnaires are very valid. The average result of the N-Gain value of students is 0.96 , based on the N-Gain criteria scale shows high criteria so that the media is said to be effective, and the results of the calculation of students' questionnaire responses show that each statement point is greater by $70 \%$ and the students can be said to be good in ability operate the gadget.
\end{abstract}

Keywords: Development; effectiveness; learning media.

\begin{abstract}
Abstrak
Tujuan penelitian ini adalah mendeskripsikan efektivitas media pembelajaran yang menghasilkan media valid, efektif dan praktis. Berkembangnya komunikasi dan teknologi menuntut guru untuk lebih aktif dan kreatif dalam melaksanakan pembelajaran di kelas. Guru bisa mengembangkan media pembelajaran yang mampu meningkatkan hasil belajar siswa. Sampel uji coba penelitian ini adalah siswa kelas $X$ di MAN 1 Mojokerto. Penelitian ini menggunakan metode penelitian 4-D yang dipersingkat menjadi 3-D. Teknik pengumpulan data yang digunakan meliputi wawancara pada guru matematika, soal pretest dan posttest. Instrumen yang digunakan penelitian ini meliputi panduan penggunaan media, bahan ajar, lembar validasi, angket respon peserta didik dan tes. Hasil penelitian ini menunjukkan bahwa rata-rata validasi panduan penggunaan media dan bahan ajar adalah 95,15\%, selain itu validator juga memberikan penilaian pada lembar angket respon sebesar 97,5\%. Hal ini menyatakan bahwa panduan media, bahan ajar dan angket respon sangat valid. Hasil rata-rata nilai N-Gain peserta didik sebesar 0.96, berdasarkan skala kriteria N-Gain menunjukkan kriteria tinggi sehingga media dikatakan efektif dan hasil perhitungan respon angket peserta didik menunjukkan tiap poin pernyataan lebih besar dengan 70\% sehingga peserta didik dapat dikatakan baik dalam kemampuan mengoperasikan gadget.
\end{abstract}

Kata kunci: Efektivitas; pengembangan; media pembelajaran

This is an open access article under the Creative Commons Attribution 4.0 International License 
DOI: https://doi.org/10.24127/ajpm.v10i3.3832

\section{INTRODUCTION}

Mathematics is a field of knowledge which useful for today's life so that the mathematics learning process does as well as possible to create a fun learning atmosphere and the students can do mathematics learning activities well (Karimah et al., 2017). Mathematics must be mastered by all students in order to have the ability to think logically, analytically, systematically, critically, and creatively (Salsabila, 2019). Creative thinking is a habit of the mind that is trained by paying attention to the ability to understand something without reasoning outside of consciousness that comes suddenly and generates unexpected ideas. So in learning mathematics, it can increase knowledge related to everyday life (Maricica \& Spijunovicb, 2015; Ummah et al., 2019).

In the junior high school level, students will learn mathematical concepts based on understanding mathematical concepts obtained in elementary school, as well as in high school level the students will learn mathematical concepts based on concepts obtained in junior high school (Rachmawati et al., 2020; Rohaeti et al., 2019). So that in mathematics learning activities that ask students just to know or remember some of the concepts being studied need to be abandoned (Kenedi et al., 2019). Previous research stated that mathematics learning that still used teacher-centered is more interactive by using learning media (Syafitri et al., 2018). If the previous research still used teacher-centered learning so in this research focuses on the use of media with a student-centered approach where the media is fully operated by students until they can find concepts.
Learning media are objects that are used to streamline communication and interaction between teachers and students in the learning process in the classroom to achieve certain goals, de provide variations in reality teaching so that the student's experience is more concrete and optimize existing teaching materials (Aditya, 2018; Suddin \& Deda, 2020; Wewe \& Juliawan, 2019). The education or learning process is identical to the communication process (Prasasti et al., 2019). Learning information conveyed by the message source to the target or recipient of the message (Umar, 2014). According to the statement above, what is meant by the source of the message is the content of education or teaching that contained in curriculum performance, while the recipient of the message is a process where students understand the message so they can describe the delivered message (Prasasti et al., 2019).

Appropriate use of media can overcome the passive attitude of students during the learning process. In order for the learning media to be chosen appropriately, so several factors are considered in the selection of learning media including objectivity, effectiveness, and efficiency. Objectivity is a learning medium chosen for learning purposes, not for the pleasure or needs of educators (Yusmiono, 2018). The effectiveness of learning media can be seen in utilizing the media used to achieve results in accordance with the desired purpose (Badriyah, 2015).

The selection of learning media is based on the planned needs of students, especially with regard to objectives that are in accordance with the material to be delivered (Mardhiah \& Ali Akbar, 2018). The selection of learning media that is really adapted to the general 
characteristics to make it easier for students to understand the learning material that will be presented by the teacher. The process of selecting learning media is the beginning of technological development, selected and determined to solve learning problems faced by students (Abidin, 2016).

The development of technology and communication is very influential in today's era so that in the learning process teachers need to provide new techniques (Muti et al., 2014). Various research show that information and communication technology (ICT) is able to change the technique of the learning process that can be used as an interesting medium for learning interactive mathematics. The development of information and communication technology encourages students to adapt and use it well both inside and outside the classroom (Apsari \& Rizki, 2018; Rizki \& Wildaniati, 2015).

Education in the 21 st century is a digital period of education in the era of ICT that is integrated with the learning process, besides learning skills that need to be mastered by students to face the development of the $21 \mathrm{st}$ century by learning skills, information skills, media, technology and innovation (Putri \& Aznam, 2019). Teachers provide ways of thinking to students which is needed in the development of the $21 \mathrm{st}$ century, besides providing ways to use technology well (Goktepe, 2014). So it is necessary to use technology that can be used to carry out innovative learning reforms and attract the attention of students. Some results of various research shows that the most effective learning media used to achieve the quality of education in entering the current era of globalization is the use of ICT (Rusmana, 2012).
Based on the facts in the field, previous research stated that learning linear equations of three variables using Microsoft office powerpoint technology media based on visual basic for applications (VBA). Visual Basic for Applications (VBA) is an additional function found in Microsoft Office, like Microsoft Word, Microsoft Excel, Microsoft Access, and Microsoft PowerPoint. The advantages of visual basic for applications (VBA) are helping the learning process, various ideas, and innovation capabilities related to learning materials into software (Mubarok \& Zahroh, 2018).

Competence in learning mathematics becomes mathematical problem solving, mathematical communication, mathematical reasoning, mathematical connections, and mathematical representation. Indicators on communication skills include: expressing real objects with everyday events in the form of mathematical models, completing mathematical models, making mathematical questions learned, listening, writing, discussing, formulating definitions, explaining and making questions about mathematics being studied (Rahmawati et al., 2019). The mathematical communication ability obtained by students is the ability of students to express a mathematical idea orally and writing in mathematical problems (Habsah, 2017).

The weakness of mathematical communication skills of students make a slow ability to solve problems, therefore mathematical communication needs to be developed in students to support increasing learning outcomes (Supriadi \& Damayanti, 2016). The existence of good mathematical communication skills, it can build an understanding of the concepts being studied. Mathematical communication 
is one of the important things in learning mathematics because basically, communication aims to convey useful messages and information to stimulate students' thoughts, feelings, and learning interests (Utari et al., 2020).

A linear media system is a smartphone-based media. The mathematics learning application can be used by students without paying. Smartphones can be used as opportunities in education because many students use smartphones when they are learning. In addition, the existence of smartphones can develop learning media to be interactive (Wafiyah \& Wintarti, 2019). Linear media systems can help to solve math problems more quickly and easily in teaching important basic concepts. Features of the linear media system, include the solution menu to determine the process of the problem so that the linear media system feature is able to solve problems in algebra learning.

The purpose of this research is to test the effectiveness of learning media that produces valid, effective, and practical learning media. Learning media is said to be effective if the students' pretest and posttest results show moderate criteria based on the $\mathrm{N}$ gain criteria scale. The thing that distinguishes previous research from this research is the technological media in the form of a linear system media that can be directly operated by students to make it easier for students to understand the material and solve problems.

\section{METHOD}

The method used in this study is an Research and Development flow chart. This research method was used to develop an effective product (Mayani \& Rizki, 2016; Syafitri et al., 2018). The method chosen is the 4D development models consists of 4 stages, these are defining, designing, developing, and disseminating (Yahya et al., 2020).

The test subjects in developing the product were 12 students in tenth class MAN 1 Mojokerto located on the street Hasanuddin number 38 Mojosari, Indonesia. The object of this research is a gadget-based on the application on the material of a three-variable linear equation system. The application is called a "linear system". Research is focused on students.

Define is an activity that doing to investigate the ability to operate gadgets in mathematics learning at MAN 1 Mojokerto, Mojosari to diagnose any problems experienced during the learning process activities using a linear system media in operating gadgets in mathematics subjects. This step was carried out by interviewing the mathematics teacher of ten class and ten class students of MAN 1 Mojokerto. With the existence of a linear media system, students are able to solve problems and the abilities of students in operating gadgets.

The second stage is the design stage. The researcher conducted a design that included teaching materials and media usage guides. The media design is in the form of a display when clicking on a three-variable linear equation system, a display when entering numbers from a three-variable linear equation system, and a display of the solution to the problem. In addition, test questions and teaching materials are arranged in such a way at this stage to support students to be more active in learning activities. In addition, there is a flowchart on the linear media system. It can be seen in Figure 1.

Researchers do a design that includes teaching materials based on learning indicators. The effectiveness 
criteria can be seen from the results of the pretest and posttest of students with minimum criteria for learning completeness of 75 .

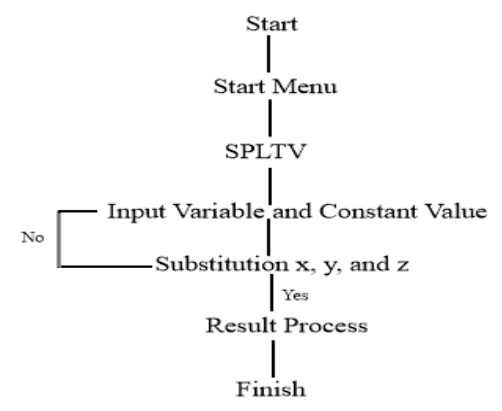

Figure.1 Flowchart of the use of linear media system

The third stage is the development stage. This stage aims to create learning media in the form of linear system media. The steps taken in this stage are the assessment of the validator carried out by referring to the validation instrument as well as providing suggestions and comments on the developed learning tools. In addition, product design trials are carried out to determine effectiveness. The validation results from the validator contained quantitative data in the form of scores.

After the learning tools have been validated, they are applied to the learning process. After that, testing of a linear system media. This stage is the core stage of the research because at this stage the linear system media is applied to learning activities in learning the three-variable linear equation system taken by class ten of MAN 1 Mojokerto because the average daily test results have not reached the minimum category of learning mastery in the previous teaching.

The last stage is the disseminate stage. This stage cannot be carried out due to time and cost limitations, so the researcher has only done at the develop stage.
The instruments in this study include media usage guidelines, worksheets, tests, validation sheets, and student response questionnaires. Interviews were conducted at the define stage to find out what problems were experienced during the teaching and learning process activities and to apply the developed learning tools. The validation sheet is used at the design and development stages to measure the validity of the learning device. In addition, the results of the pretest and post-test of students to measure learning media effectiveness.

Qualitative data at the define stage are the results of interviews with teachers and students and notes on the results of the study of the teacher's learning implementation plan. While at the development stage there are qualitative data and quantitative data. Qualitative data were obtained from suggestions and comments from validators on learning tools in the form of questionnaires, student worksheets, and media guides. Quantitative data were obtained from the score of the questionnaire validator of learning devices and the results of the scores on the student competency test in the form of the results of the pretest and post-test of students. The data collection technique was tested by 12 students. In the first meeting, students were given test questions in learning a threevariable system of linear equations. The test questions are in the form of a description consisting of 4 questions that are done in 70 minutes. In addition, the test questions are obtained from the UN/SBMPTN questions so they do not need to be validated. Students are guided in using the linear system media. Worksheets (LK) are given after the researcher guides students in using the linear system media. 
DOI: https://doi.org/10.24127/ajpm.v10i3.3832

The effectiveness of the developed learning device can be determined by calculating the $\mathrm{N}$-gain value. Gain is an increase in the ability of learning outcomes after carrying out learning activities. The purpose of calculating the $\mathrm{N}$-gain is to avoid errors in interpreting the gain of each student. $\mathrm{N}$-gain is calculated using the following formula:

$$
g=\frac{S_{\text {post }}-S_{\text {pre }}}{S_{\text {maks }}-S_{\text {pre }}}
$$

(Sari \& Sumuslistiana, 2018)

Note :

$g \quad=\mathrm{N}$-gain

$S_{\text {post }}=$ Post-test score

$S_{\text {pre }}=$ Pretest score

$S_{\text {maks }}=$ Maximun score

$\mathrm{N}$-gain criteria values as follows:

$\begin{array}{ll}g \geq 0,7 & =\text { High } \\ 0,3 \leq g<0,7 & =\text { Moderate } \\ g \leq 0,7 & =\text { Low }\end{array}$

The effectiveness test can be seen from the analysis of the students' pretest and posttest results. In addition, based on the $\mathrm{N}$-gain criterion scale, it shows moderate criteria so that the learning device in the form of a linear media system is said to be effective.

\section{RESULT AND DISCUSSION}

Activities at the define stage analyze the ability to operate gadgets to find out what problems are experienced by students. The analysis step that doing by interviewing students in class ten and mathematics teachers in class ten. Information obtained from interviews is that the density of learning materials causes students to have difficulty in solving problems in the material being taught, while the teacher states that students are less enthusiastic about learning and what they are doing in the class, for example, talking to a classmate so that if given a problem students have difficulty solving problems, even though each student is required to achieve the minimum category of learning completeness.

Activities done at the design stage produce validation results and media test results. The results carried out at the design stage include validation activities, the validator states that every aspect of the "very valid" category with improvements at the design stage of the teaching materials is less attractive, so it needs to be given a picture. The media guide validation sheet and response questionnaire need to be improved on the indicators. So that these aspects are adjusted to the validity aspects that exist in previous research. In this study, the expert validators who tested the feasibility of using a linear system media guide and teaching materials were the Mathematics Education Lecturer at the University of Muhammadiyah Malang and the Mathematics Teacher. Previous research stated that media and teaching materials must pass the validation stage because the media will be reviewed by the validator so that the media and teaching materials are considered suitable for learning (Anwar et al., 2019; Rizki \& Linuhung, 2016).

The validation results from validator 1 show that the presentation of the guide score for using linear system media and teaching materials is $92,8 \%$, while validator 2 gets a score of $97,5 \%$ so that the average of the two validators is $95,15 \%$. This data shows that the guide to the use of linear system media and teaching materials is very valid. Expert validators not only provide an assessment of the guidelines for using the linear system media and teaching materials, but also the questionnaire 
response validation sheet. The average of the two validators is $97,5 \%$. This shows that the response questionnaire is very valid and can be distributed after the research is completed as a reference to test the effectiveness of the linear media system.

The results of the implementation trial at the first meeting of students were given pretest questions first. After that, students are guided in the use of linear media systems.

\section{Learning Media Guide}

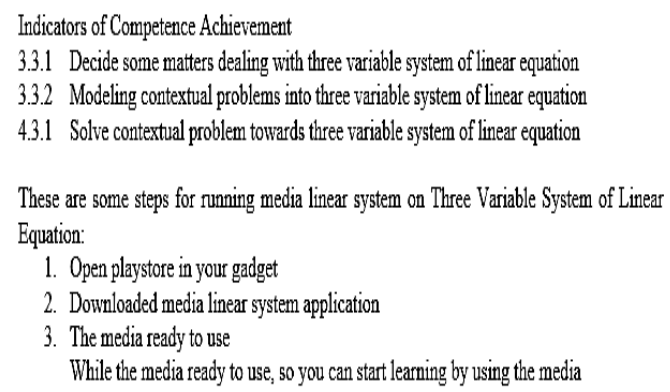

Figure.2 Linear system media handbook

Based on Figure 2, it can be shown the appearance of the linear system media manual and an explanation of the linear system media description. Students are asked to read the instructional media guide provided before the learning takes place. After that, students fill out the Worksheet (LK), at this stage, it produces student responses in the form of questions on the Worksheet (LK) because students do not understand the problem. In addition, students at the time of learning were asked to observe the core menu of the linear media system as shown in Figure 3. Based on Figure 3, it can be seen that the menu display has elements in the form of numbers from the variable equation, the duration of giving media is approximately one hour.

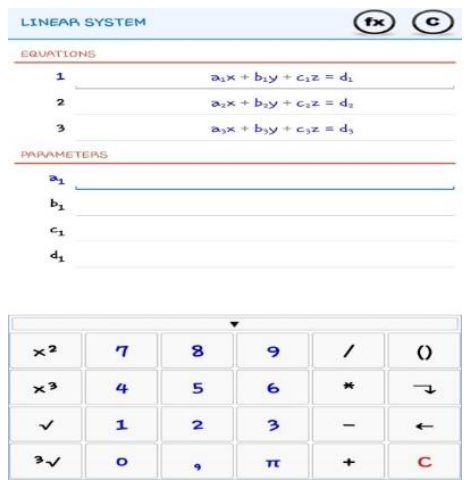

Figure.3 Display of linear system media core menu

The application of learning media when it takes place does not occur obstacles so that students can practice directly on their respective gadgets, then students must fill in the numbers of variables and constants according to the problems in question. When students fill in numbers, there are obstacles, namely errors in entering the value of the variable. Then this problem was solved by equating to zero to find out the value of the variable from the example problem. In addition, students are asked to answer the mathematical model in the problem. When the display appears on the media, the teacher asks what is the meaning of the display of $a_{1}, b_{1}$, and $c_{1}$ students, as many as $50 \%$ of the students answered correctly that what the teacher appointed was to show the number of the 1 st $x$ variable, $b_{1}$ is the number of the $y$ th variable 1 and $c_{1}$ are the numbers of the 1 st $z$ variable. After that, the teacher asked again the meaning of the display of $a_{3}, b_{3}$ and $c_{3}$ to the students, the students answered correctly that what the teacher was pointing at was the number of the variable representing the $3 \mathrm{rd} x$ variable, $b_{3}$ showing the number of the $3 \mathrm{rd} y$ variable and $c_{3}$ shows the number of the 3rd $z$ variable. If students already know the number of variables, then students can apply it to media application. 
DOI: https://doi.org/10.24127/ajpm.v10i3.3832

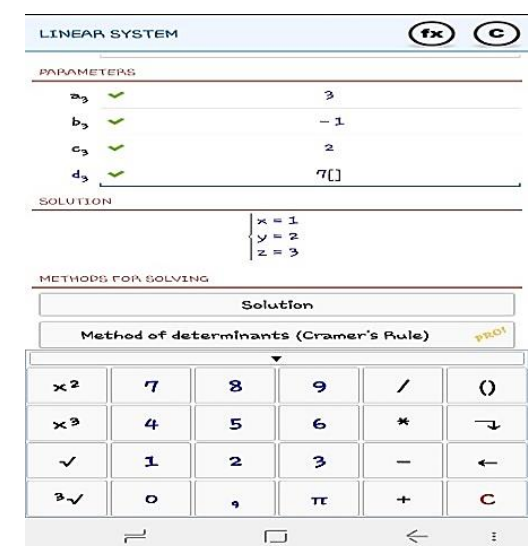

Figure.4 Results of using media

Figure 4 shows the solution of the material for a system of three-variable linear equations, at this stage students were asked to identify the results of the solution using the substitution and elimination method from the equation. As many as $50 \%$ of students can identify the stages or steps in solving problems using the substitution and elimination methods. The display of the results of using the media aims to find out the solution to the problem so that students must fill in the numbers of the variables correctly.

The final learning meeting was held to work on posttest questions offline to find out the extent to which students' understanding was used to determine the effectiveness of the linear media system. The results of the pretest and post-test scores will be used to determine the value of $\mathrm{N}$-Gain to test the effectiveness of the linear media system. The results of the pretest with an average of $77,1 \%$ and the results of the post-test with an average of $86,1 \%$. The results of the effectiveness test data analysis showed that from 12 students, the average $\mathrm{N}$-Gain value was 0,96 . Based on the N-Gain criteria scale, it shows high criteria so that the linear media system is said to be effective and each student gets a score greater than 75. After that, students were asked to fill out a response questionnaire to determine the ability of students to operate gadgets.

Based on the student response questionnaire $87,5 \%$ were obtained with the "very good" category in the aspect of the ability to operate gadgets on a linear system media, so that the media was equipped with operational instructions. In addition, easy-to-follow media operational instructions received $81,2 \%$ of responses from students with the "good" category, this is in accordance with previous research stating that media can facilitate students to learn anywhere and anytime (Aliffuddin et al., 2018). The response of students to the mathematical notation in the media was obtained by $85,4 \%$ with the "very good" category based on the aspect of understanding the material, so that the linear system media according to the material in the book or taught by the teacher received a student response of $92 \%$ with the category "very good". This is in accordance with previous research that media can help students understand linear program material and it can increase students' motivation in studying the material in the "very good" category (Aliffuddin et al., 2018). The success of this research is seen from the results of the response questionnaire in the ability to operate gadgets seen from the results of the percentage of each statement item greater than $70 \%$ of the number of students.

The findings in this study are that the linear system media is said to be effective based on the average n-gain value of 0.96 indicating high criteria and students have the ability to operate gadgets in learning mathematics. The advantage of this research is that students can improve learning outcomes, while the drawback is the 
teacher is not always able to guide students in the understanding the concept of using media. This research is in line with previous research that media in learning can motivate and improve student learning. In addition, based on the student response questionnaire it shows a very good category (Aliffuddin et al., 2018). In previous research, gadget-based media helped students understand, and help solve problems to improve learning outcomes (Sari \& Sumuslistiana, 2018). This is inversely proportional to previous research that the learning media still has not improved student learning outcomes showing less or low criteria (Wahyu et al., 2014). This study has positive impact for improving student's skills to operate learning media.

\section{CONCLUSION AND SUGGESTION}

Based on the results and discussion in this study, it can be concluded that the guide to the use of linear media systems and teaching materials can be said to be very valid with an average score of $95,15 \%$. The students' test scores show that the average $\mathrm{N}-$ Gain value is 0,96 shows high criteria so that the linear media system is said to be effective. The response questionnaire given to students gets a percentage of more than $70 \%$ of each item statement so that students have good skills in operating gadgets.

This study has a drawback, namely the teacher is not always able to guide students in the understanding the concept of using media, therefore in further research, it is recommended that the media can be given a guidebook to provide questions that are the evaluation of the use of media.

\section{REFERENCES}

Abidin, Z. (2016). Penerapan Pemilihan Media Pembelajaran. Edcomtech, 1(1), 9-20.

Aditya, P. T. (2018). Pengembangan Media Pembelajaran Matematika Berbasis Web Pada Materi Lingkaran Bagi Siswa Kelas Viii. Jurnal Matematika Statistika Dan Komputasi, 15(1), 64-74. https://doi.org/10.20956/jmsk.v15i 1.4425

Aliffuddin, M. N., Taufik, A., \& Adiastuty, N. (2018). Pengambangan Media Pembelajaran Internet Interaktif Mobile Learning Berbasis Android pada Materi Program Linier Kelas XI SMA. Prosiding Seminar Nasional Pendidikan Matematika, 203-215.

Almarabeh, H., Amer, E. F., \& Sulieman, A. (2015). The Effectiveness of Multimedia Learning Tools in Education. International Journal of Advanced Research in Computer Science and Software Engineering, 5(12), 761764.

https://www.researchgate.net/publi cation/290429349_The_Effectiven ess_of_Multimedia_Learning_Tool s_in_Education

Anwar, M. S., Choirudin, Ningsih, E. F., Dewi, T., \& Maseleno, A. (2019). Developing an Interactive Mathematics Multimedia Learning Based on Ispring Presenter in Increasing Students' Interest in Learning Mathematics. Al-Jabar: Jurnal Pendidikan Matematika, 10(1), 135-150. https://doi.org/10.24042/ajpm.v10i 1.4445

Apsari, P. N., \& Rizki, S. (2018). Media Pembelajaran Matematika Berbasis Android Pada Materi Program 
DOI: https://doi.org/10.24127/ajpm.v10i3.3832

Linear. AKSIOMA Journal of Mathematics Education, 7(1), 161170.

https://doi.org/10.1299/jsmemag.1 21.1191_47

Badriyah. (2015). Efektifitas Proses Pembelajaran Dengan Pemanfaatan Media Pembelajaran. Jurnal Lentera Komunikasi, 1(1), 21-36.

Goktepe, S. (2014). A WebQuest Example for Mathematics Education. Procedia - Social and Behavioral Sciences, 116, 21752179.

https://doi.org/10.1016/j.sbspro.20 14.01.539

Habsah, F. (2017). Developing teaching material based on realistic mathematics andoriented to the mathematical reasoning and mathematical communication. Jurnal Riset Pendidikan Matematika, 4(1), 43-55. https://doi.org/10.21831/jrpm.v4i1. 10199

Karimah, A., Rusdi, R., \& Fachruddin, M. (2017). Efektifitas media pembelajaran matematika menggunakan software animasi berbasis multimedia interaktif model tutorial pada materi garis dan sudut untuk siswa SMP/Mts kelas VII. Jurnal Penelitian Pembelajaran Matematika Sekolah (JP2MS), 1(1), 9-13. https://doi.org/10.33369/jp2ms.1.1. 9-13

Kenedi, A. K., Helsa, Y., Ariani, Y., Zainil, M., \& Hendri, S. (2019). Mathematical connection of elementary school students to solve mathematical problems. Journal on Mathematics Education, 10(1), 6979.

https://doi.org/10.22342/jme.10.1.5 416.69-80

Mardhiah, A., \& Ali Akbar, S. (2018).
Efektivitas Media Pembelajaran Terhadap Hasil Belajar Kimia Siswa Sma Negeri 16 Banda Aceh. Lantanida Journal, 6(1), 1-102. https://doi.org/10.22373/lj.v6i1.31 73

Maricica, S., \& Spijunovicb, K. (2015). Developing Critical Thinking in Elementary Mathematics Education through a Suitable Selection of Content and Overall Student Performance. Procedia Social and Behavioral Sciences, 180, 653-659. https://doi.org/10.1016/j.sbspro.20 15.02.174

Mayani, S., \& Rizki, S. (2016). Pengembangan Bahan Ajar Berbasis Pendidikan Matematika Realistik (PMR) Pada Materi Program Linear. AKSIOMA Journal of Mathematics Education, 5(1), 25-39.

Mubarok, M. U., \& Zahroh, U. (2018). Pengembangan Media Pembelajaran Matematika dengan Power Point VBA pada Materi Sistem Persamaan Linear Tiga Variabel. Prosiding SI MaNIs (Seminar Nasional Integrasi Matematika Dan Nilai-Nilai Islami), 2(1), 38-45.

Muti, N. F. B. A., Nadzri, F. A., \& Rom, K. B. B. M. (2014). Teaching with Technology: Implications for Preparatory Programmes of Science and Mathematics Educators. Procedia Social and Behavioral Sciences, 123, 145-150. https://doi.org/10.1016/j.sbspro.20 14.01.1408

Prasasti, T. I., Solin, M., \& Hadi, W. (2019). The Effectiveness of Learning Media Folklore Text of North Sumatera Based on Blended Learning by 10th Grade Students 
DOI: https://doi.org/10.24127/ajpm.v10i3.3832

of Vocational High SchoolHarapan Mekar-1 Medan. Budapest International Research and Critics in Linguistics and Education (BirLE) Journal, 2(4), 480-490. https://doi.org/10.33258/birle.v2i4. 548

Putri, A. S., \& Aznam, N. (2019). The Effectiveness of Science Learning Media Using Focusky Software on Junior High School Students' Higher Order Thinking Skills. Scientiae Educatia, 8(1), 12-22. https://doi.org/10.24235/sc.educati a.v8i1.3886

Rachmawati, A. D., Baiduri, \& Effendi, M. M. (2020). Efektivitas Media Pembelajaran Interaktif Berbantuan Web Dalam Mengembangkan Kemampuan Berfikir Kreatif. AKSIOMA Journal of Mathematics Education, 9(3), 540-550. https://doi.org/https://doi.org/10.24 127/ajpm.v9i3.3014

Rahmawati, N. S., Bernard, M., \& Akbar, P. (2019). Analisis Kemampuan Komunikasi Matematik Siswa Smk Pada Materi Sistem Persamaan Linier Dua Variabel (SPLDV). Journal On Education, 1(2), 344-352.

Rizki, S., \& Linuhung, N. (2016). Pengembangan Bahan Ajar Program Linear Berbasis Kontekstual Dan Ict. AKSIOMA Journal of Mathematics Education, 5(2), 137-144. https://doi.org/10.24127/ajpm.v5i2. 674

Rizki, S., \& Wildaniati, Y. (2015). Efektifitas Bahan Ajar Dan Media Berbasis Ict Pada Materi Persamaan Dan Fungsi Kuadrat. AKSIOMA Journal of Mathematics Education, 4(2), 1-8. https://doi.org/10.24127/ajpm.v4i2.
292

Rohaeti, E. E., Bernard, M., \& Primandhika, R. B. (2019). Developing interactive learning media for school level mathematics through open-ended approach aided by visual basic application for excel. Journal on Mathematics Education, 10(1), 59-68. https://doi.org/10.22342/jme.10.1.5 391.59-68

Rusmana, I. M. (2012). Efektivitas Penggunaan Media Ict Dalam Peningkatan Pemahaman Konsep Matematika. Formatif, 2(3), 198205.

https://doi.org/10.30998/formatif.v 2i3.102

Salsabila, E. (2019). Influence of prerequisite concepts understanding and mathematical communication skills toward student's mathematical proving ability. Pythagoras: Jurnal Pendidikan Matematika, 14(1), 46-55.

https://doi.org/10.21831/pg.v14i1.2 5067

Sari, I. W., \& Sumuslistiana. (2018). Aplikasi Mobile Learning Berbasis Android sebagai Media Pembelajaran pada Materi Program Linear Kelas XI di SMA Widya Dharma Surabaya. MUST: Journal of Mathematics Education, Science and Technology, 3(2), 175. https://doi.org/10.30651/must.v3i2. 2000

Suddin, S., \& Deda, Y. N. (2020). Education Game based on Timor Local Wisdom as an AndroidBased Mathematics Learning Media. Al-Jabar: Jurnal Pendidikan Matematika, 11(2), 227-246.

https://doi.org/10.24042/ajpm.v11i 2.6958 
Supriadi, N., \& Damayanti, R. (2016). Analisis Kemampuan Komunikasi Matematis Siswa Lamban Belajar dalam Menyelesaikan Soal Bangun Datar. Al-Jabar: Jurnal Pendidikan Matematika, 7(1), 1-9. https://doi.org/https://doi.org/10.24 042/ajpm.v7i1.21

Syafitri, Q., Mujib, C. A., Netriwati, \& Wawan. (2018). The Mathematics Learning Media uses Geogebra on the Basic Material of Linear Equations. Al-Jabar: Jurnal Pendidikan Matematika, 9(1), 918.

Umar. (2014). Media Pendidikan. Jurnal Tarbawiyah, 11(1), 131144.

https://doi.org/10.28944/afkar.v5i1 .109

Ummah, S. K., Inam, A., \& Azmi, R. D. (2019). Creating manipulatives: Improving students' creativity through project-based learning. Journal on Mathematics Education, 10(1), 93-102. https://doi.org/10.22342/jme.10.1.5 093.93-102

Utari, D., Utomo, D. P., \& Zukhrufurrohmah. (2020). Effectiveness of the application of Quantum Learning Model in terms of students' written mathematical communication skills. Mathematics Education Journals, 4(2), 177-186.

Wafiyah, I., \& Wintarti, A. (2019). Pengembangan Media Pembelajaran M-Learning Berbasis Android Pada Materi Spldv. Jurnal Ilmiah Pendidikan Matematika, 8(2), 124-127.

Wahyu, Matnuh, H., \& Triani, D. (2014). Hubungan Penggunaan Media Pembelajaran Dengan Hasil Belajar Pkn Pada Siswa Kelas X Dan XI Di SMA Muhammadiyah 1
Banjarmasin. Jurnal Pendidikan Kewarganegaraan, 4(7), 530-536.

Wewe, M., \& Juliawan, I. W. (2019). Developing Mathematical Devices with Characteristics Realistic Mathematics Education. Al-Jabar: Jurnal Pendidikan Matematika, 10(1), 1-10. https://doi.org/10.24042/ajpm.v10i 1.3884

Yahya, R., Ummah, S. K., \& Effendi, M. M. (2020). Pengembangan Perangkat Pembelajaran Flipped Classroom Bercirikan MiniProject. SJME (Supremum Journal of Mathemathics Education), 4(1), 78-91.

Yusmiono, B. A. (2018). Media pembelajaran visual terhadap hasil belajar mahasiswa program studi pendidikan geografi di universitas PGRI Palembang. Faktor Jurnal Ilmiah Kependidikan, 5(1), 1-8. 